\title{
Graptolite biostratigraphy of the E1-NC174 core, Rhuddanian (lower Llandovery, Silurian), Murzuq Basin (Libya)
}

\author{
DAVID K. LOYDELL
}

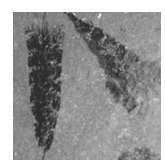

\begin{abstract}
The graptolite biostratigraphy of the Rhuddanian (lower Llandovery, Silurian) of the E1-NC174 core, Murzuq Basin, Libya is described. The generally low diversity graptolite assemblages include both North African endemic taxa and cosmopolitan species. The lower part of the cored interval, below the 'hot' shale, is dominated by Normalograptus tilokensis, a species previously considered to be confined to the Upper Ordovician, but which almost certainly ranges into (or perhaps occurs only in) the lower Silurian. As in the BG-14 core, Jordan, the base of the 'hot' shale lies just above the first appearances of Neodiplograptus africanus and Normalograptus rectangularis. The latter species dominates throughout the mid Rhuddanian 'hot' shale interval, with the highest strata in the core, of late Rhuddanian age, yielding abundant Neodiplograptus fezzanensis. $\bullet$ Key words: Silurian, Libya, graptolite, Llandovery, Rhuddanian, hot shale, North Africa, Tanezzuft.
\end{abstract}

LOYDELL, D. 2011. Graptolite biostratigraphy of the E1-NC174 core, Rhuddanian (lower Llandovery, Silurian), Murzuq Basin (Libya). Bulletin of Geosciences 87(4), 651-660 (3 figures, 7 tables). Czech Geological Survey, Prague. ISSN 1214-1119. Manuscript received August 19, 2011; accepted in revised form January 3, 2012; published online April 17, 2012; issued October 17, 2012.

David K. Loydell, School of Earth and Environmental Sciences, University of Portsmouth, Burnaby Road, Portsmouth PO13QL,UK; david.loydell@port.ac.uk

This paper represents the first published detailed graptolite biostratigraphical study of a 'hot' shale core from North Africa.

The E1-NC174 well (Fig. 1) was drilled in the Murzuq Basin of SW Libya. This large, intracratonic structural basin extends east and south from Libya into western Algeria and northern Niger. Important hydrocarbon source rocks (organic-, and uranium-rich - hence 'hot' - shales) occur within the basin where they overlie glacial deposits (often acting as a reservoir, with the 'hot' shales acting as a seal) of Late Ordovician age. The cored interval is from $7237^{\prime}(2205.84 \mathrm{~m})$ to $7294^{\prime}(2223.21 \mathrm{~m})$; the core has a diameter of $4^{\prime \prime}$ $(10 \mathrm{~cm})$. Note that feet and inches are used herein as these are the units used on the core storage boxes, in the original core description and in the catalogue of graptolites from the core. Lithologically, there is very little variation throughout the core: it is dominated throughout by hard, dark grey shales, all belonging to the Tanezzuft Formation.

Well logs and the core derived from the E1-NC-174 well have been the subject of considerable previous study. Published work includes that of Lüning et al. (2000) who presented maps together with TOC and gamma ray curves demonstrating the presence of a 'hot' shale in the well. More detailed TOC and gamma ray curves were produced by Lüning et al. (2003) and supplemented with Rock-Eval pyrolysis data, organic geochemical biomarker analyses, pyrite framboid data and some very limited graptolite biostratigraphy (from four core samples, based on an unpublished 1998 report for LASMO by Loydell).

In November 1999 the opportunity arose to sample the E1-NC174 core more thoroughly, for graptolite biostratigraphical work and palynological studies. Funding from Eni, from 2005-2007, enabled examination of this material. The present paper is based upon study of 82 samples from depths ranging from $7237^{\prime} 2^{\prime \prime}(2205.89 \mathrm{~m})$ to $7293^{\prime} 10^{\prime \prime}$ ( $\left.2223.16 \mathrm{~m}\right)$. Of these, 67 samples yielded graptolites identifiable to species level, with the total number of graptolites examined in excess of 500. In terms of preservation, with the exception of three-dimensional pyrite internal moulds from $7266^{\prime} 9^{\prime \prime}$ and 7267 '1/2", virtually all specimens are preserved flattened (the few exceptions are preserved in very low relief). There is no tectonic deformation of the rhabdosomes. All figured specimens are housed at the British Geological Survey, Keyworth. 


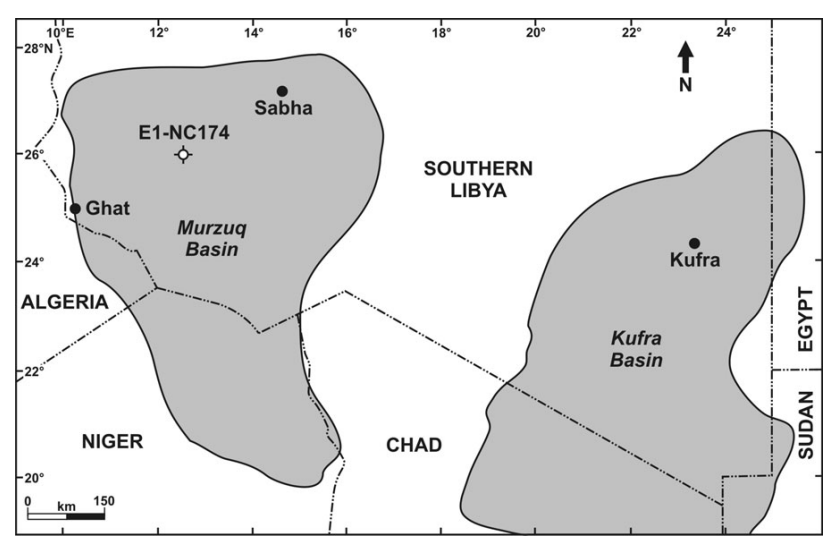

Figure 1. Location of the E1-NC174 well, Libya.

\section{Previous work on Libyan graptolites}

There have been several published works which include graptolite data from Libya: the summary of these here is limited to papers with illustrations and/or descriptions; papers with faunal lists only are excluded.

Desio (1940) described 12 graptolite taxa from western Libya. He erected two new species, both of which have subsequently been shown to be common and stratigraphically important: Climacograptus (now Paraclimacograptus) libycus and Diplograptus (now Neodiplograptus) fezzanensis. Some of Desio's material was re-examined by Štorch \& Massa (2006) and in some cases assigned to different taxa.

Jaeger (1976) illustrated two specimens from SW Libya as Climacograptus innotatus brasiliensis Ruedemann in Maury, 1929. Loydell (2007) referred this material to Paraclimacograptus libycus.

Parizek et al. (1984) illustrated some lower and middle Llandovery graptolites from the Al Qarqaf Arch region.

El-Chair et al. (1985) illustrated C. innotatus brasiliensis from Tahale, SW Libya: this material also appears to be $P$. libycus (based upon the distinguishing features of this taxon noted by Storch \& Massa 2006). Lüning et al. (1999) illustrated Neodiplograptus fezzanensis from the Kufra Basin, SE Libya.

Štorch \& Massa (2004) provided a very useful overview of the Llandovery and Wenlock graptolites of Libya. Štorch \& Massa (2006) described 23 species from the Aeronian of the Al Qarqaf Arch region; and Storch \& Massa (2007) described three species from the middle Telychian from cores in NW Libya.

Graptolites from neighbouring Algeria have been studied over a long period by Legrand (1969, 1970, 1977, 1978, 1979, 1986a, 1986b, 1995, 1998, 1999, 2000, 2001, 2002, 2003, 2009) whose papers include descriptions of many important species found also in Libya.

\section{Graptolite biostratigraphy of the E1-NC174 core and age of the 'hot' shale}

Figure 2 illustrates the stratigraphical ranges of graptolites within the E1-NC174 core, and shows the three biozones recognised. The graptolite assemblages are generally of low diversity and are dominated by biserials: uniserial graptolites were recorded from only four samples. There is a mixture of cosmopolitan taxa and those considered to be endemic to Gondwana and some peri-Gondwanan terranes, the latter exhibiting the high level of intraspecific variation that characterizes graptolites from these regions. There is thus a rather surprising difference in the nature of the assemblages from those from neighbouring Algeria; Philippe Legrand's extensive investigations of the Upper Ordovician and lower Silurian graptolites of Algeria (comprehensively reviewed in Legrand 1999) emphasized the endemicity of the taxa found there. Whilst several of these endemics have also been found in the E1-NC174 core, they occur together with cosmopolitan taxa, notably several species of Normalograptus, Huttagraptus acinaces (Törnquist, 1899) (Fig. 3O) and Metaclimacograptus hughesi (Nicholson, 1869) (Fig. 3R). The presence of these cosmopolitan taxa, together with knowledge gained from work in Jordan (Loydell 2007) where again Gondwanan endemics and cosmopolitan species co-occur, enables more confident integration of North African graptolite biostratigraphy with the 'standard' graptolite biozonation.

Graptolites from the core are illustrated in Fig. 3. Virtually all of the species are well-known and have been described thoroughly by Legrand (1970, 1977, 1986a, 1999, 2001) and/or Loydell (2007); thus only a few comments regarding distinguishing features are made below. A large number of measurements of rhabdosome dorso-ventral width and thecal spacing was made during the identification work. These measurements are included here (Tables 1-7) as they may be of use to workers in the future when identifying, or studying intraspecific variation in, the taxa concerned.

Many, including the lowest, of the samples from the lower part of the core bear monospecific assemblages of Normalograptus tilokensis (Legrand, 1986a) (Fig. 3D-H). As noted in the original description (Legrand 1986a), $N$. tilokensis differs from the rather similar $N$. rectangularis in being more robust (most noticeable proximally, although there is some overlap: compare DVW figures in Tables 1 and 3), in having a long, robust virgella and by its distal diminution in width. Legrand (e.g. 1986a, 1999, 2003, 2009) used $N$. tilokensis as a biozonal index and assigned the biozone tentatively to the uppermost Hirnantian, having stated (Legrand 1986a) that the North African tilokensis and overlying kiliani biozones are 'the very approximate equivalent' of the persculptus Biozone. Subsequently, Legrand (2009) considered the tilokensis Biozone to be equivalent to a Hirnantian post-persculptus Biozone 

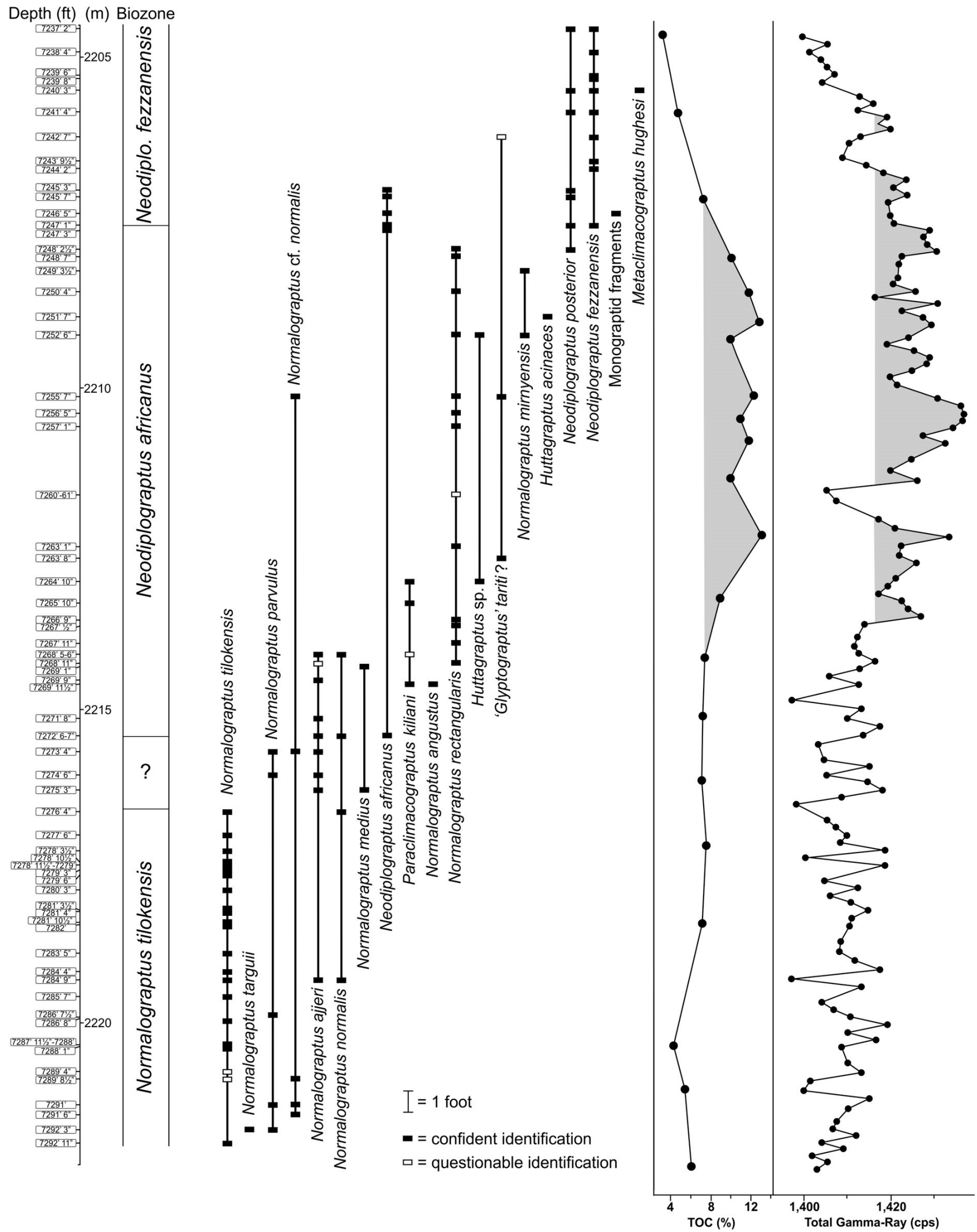

Figure 2. Stratigraphical ranges of graptolites in the E1-NC174 core, Libya. TOC and gamma-ray curves are from Lüning et al. (2003); the highest values (the 'hot' shale) are shaded. 
'interregnum' such has been recognised in Sweden (Koren' et al. 2003) and is present also in China (Chen et al. 2005; see Loydell 2007, p. 8). Lüning et al. (2000, fig. 11 and 2003, fig. 4) accepted Legrand's (1986a, 1999) proposed correlation of the tilokensis Biozone and thus the lower part of the core interval below the hot shale was assigned by them to the Upper Ordovician. Only one sample from the lower part of the core (a sample from $7285^{\circ}$ provided by LASMO) was available at the time of Lüning et al.'s work and thus the overall range of $N$. tilokensis in the core was unknown. From the much more detailed sampling undertaken for the current paper, $N$. tilokensis was found to occur from 7292' 11" up to $7276^{\prime} 4^{\prime \prime}$. This LAD poses some problems if N. tilokensis is indeed restricted to the upper Hirnantian. Neodiplograptus africanus (Legrand, 1970) (Fig. 3S, W) appears at 7272' 6". In Jordan (Loydell 2007) Ne. africanus appears close to the ascensus-acuminatus/vesiculosus Biozone boundary. It has never been recorded at a lower stratigraphical level. Thus the ascensus-acuminatus Biozone would need to be less than 4 feet $(1.22 \mathrm{~m})$ thick (i.e. very condensed) within the E1-NC174 core if $N$. tilokensis is an entirely Ordovician species. In addition, the chitinozoan Belonechitina postrobusta, a Rhuddanian chitinozoan biozonal index species (Butcher 2009), is common in samples from the base of the E1-NC174 core and throughout the range of $N$. tilokensis (Anthony Butcher, pers. comm.). It thus appears most likely that the stratigraphical range of the North African endemic graptolite Normalograptus tilokensis extends into or perhaps is entirely within the Silurian.

Normalograptus parvulus (Lapworth, 1900) (Fig. 3C) occurs within the core below the hot shale, within the tilokensis Biozone and in the unzoned interval below the FAD of Neodiplograptus africanus. This well-known and widely recorded species has a range in the 'standard' biozonation from the persculptus Biozone up to probably the lower vesiculosus Biozone (Loydell 2007).

As noted above, Neodiplograptus africanus appears at $7272^{\prime} 6^{\prime \prime}$. It is absent through much of the 'hot' shale interval, and is common at the top of the hot shale. Ne. africanus is an important North African biozonal index species (for this reason the biozone is used herein) indicating the middle of the Rhuddanian (Legrand 2003, fig. 2). The upper part of its range in the E1-NC174 core overlaps with the lower parts of the stratigraphical ranges of Neodiplograptus posterior (Legrand, 1970) (Fig. 3X, Y), which is uncommon, and the very abundant Ne.fezzanensis (Desio, 1940) (Fig. 3T-V), two taxa typical of the upper Rhuddanian, the latter being a North African biozonal index species (Legrand 2003). Ne. fezzanensis [none of which in the present collection possesses within its thecae the intriguing tubular structures described by Legrand (1978, 1979, 1986b)], has been recorded also from the Czech Republic (Štorch 1983), from both the upper
Rhuddanian Coronograptus cyphus Biozone and the lowermost Aeronian Demirastrites triangulatus Biozone. The top of the core, assigned to the fezzanensis Biozone, is thus of either late Rhuddanian or earliest Aeronian age.

Of considerable interest is the stratigraphical range of Normalograptus rectangularis (McCoy, 1850) (Fig. 3M, N) within the E1-NC174 core. As noted by Loydell (2007), $N$. rectangularis is a very useful species stratigraphically, as its first appearance is in the upper part of the ascensus-acuminatus Biozone. Its range from $7268^{\prime} 11^{\prime \prime}$ to $7248^{\prime} 2 \frac{1}{2}$ " is from the base of the 'hot' shale to a level near its top. It is the most abundant species within the 'hot' shale. It never co-occurs with $\mathrm{Ne}$. africanus despite its range being entirely within that of the latter species. A similar mutually exclusive relationship was seen in the BG-14 core, Jordan (Loydell 2007), where N. rectangularis appears close to the base of the 'hot' shale, $1.5 \mathrm{~m}$ above the FAD of Neodiplograptus africanus.

Paraclimacograptus kiliani (Legrand, 1977) (Fig. 3Z) occurs immediately below and in the lower part of the 'hot' shale in the E1-NC174 core, in the lower part of the africanus Biozone. The species (identified by Loydell 2007 as Paraclimacograptus sp.) occurs at a very similar biostratigraphical level in Jordan (Loydell 2007), within the Cystograptus vesiculosus Biozone. It occurs also in Mauritania (misidentified as Pseudorthograptus obuti by Underwood et al. 1998), again at a similar stratigraphical level, equivalent either to the upper ascensus-acuminatus Biozone or lower Cystograptus vesiculosus Biozone. As noted above, Legrand (1986a) originally considered the kiliani Biozone (which is based upon the total stratigraphical range of $P a$. kiliani) to be probably of late Hirnantian age. However, Legrand (2009) later revised this view and correlated it with the lower part of the lowermost Silurian Akidograptus ascensus Biozone. The occurrences in Libya, Mauritania and Jordan referred to above indicate a somewhat higher stratigraphical level for $\mathrm{Pa}$. kiliani and also cast doubt on its utility as a biozonal index. In both Jordan and Libya the specimens of $P a$. kiliani occur above the FADs of $N$. rectangularis and Ne. africanus, in the former case demonstrably in the middle Rhuddanian vesiculosus Biozone. In Mauritania, the $P a$. kiliani-bearing level is less than $0.5 \mathrm{~m}$ below the FAD of $N$. rectangularis (Underwood et al. 1998, fig. 3). There is thus strong evidence that this species occurs in the middle Rhuddanian. In the Oued In Djerane region of south-east Algeria the FAD of Pa. kiliani occurs stratigraphically above the LAD of $N$. tilokensis above approximately $20 \mathrm{~m}$ of strata which contain neither species (Legrand 2000, fig. 3). A similar relationship (although with a thinner intervening interval lacking both taxa) occurs in the E1-NC174 core. Given the comments above regarding the likely Silurian (rather than Hirnantian) age of the tilokensis Biozone, a FAD for Pa. kiliani at a stratigraphical level correlating approximately with the 


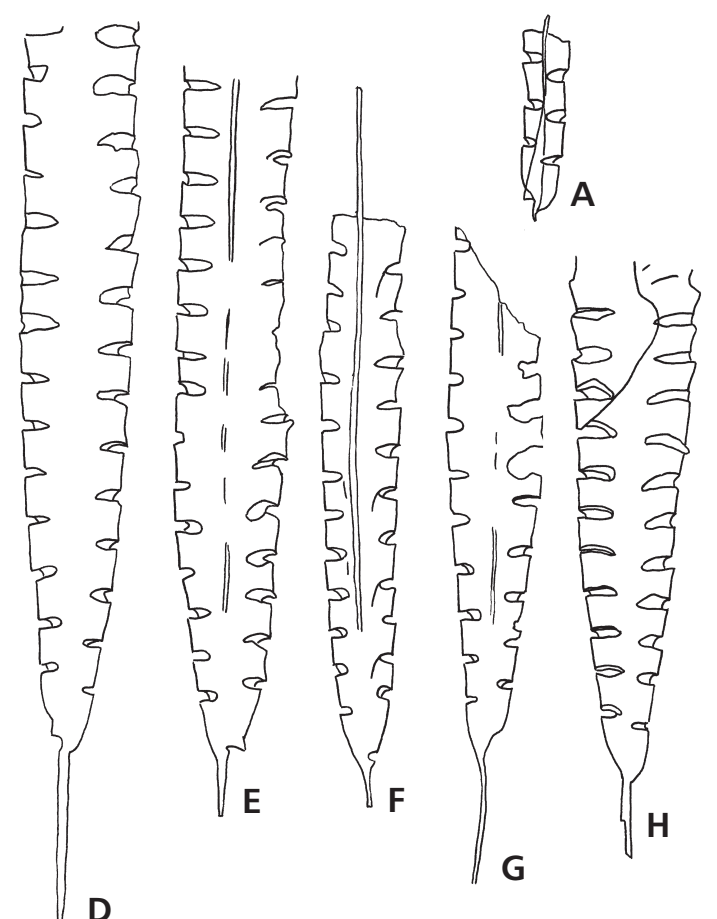

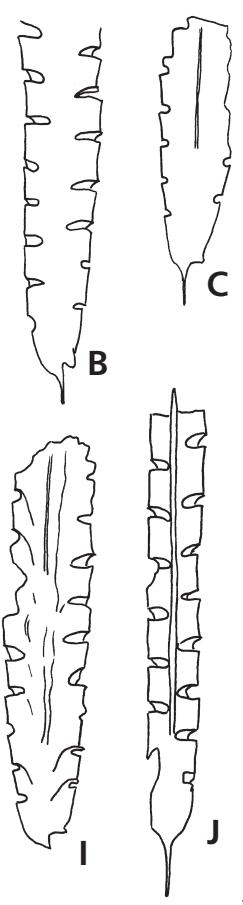

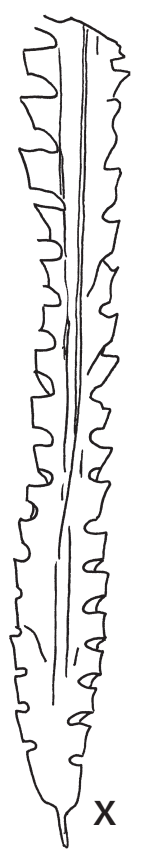

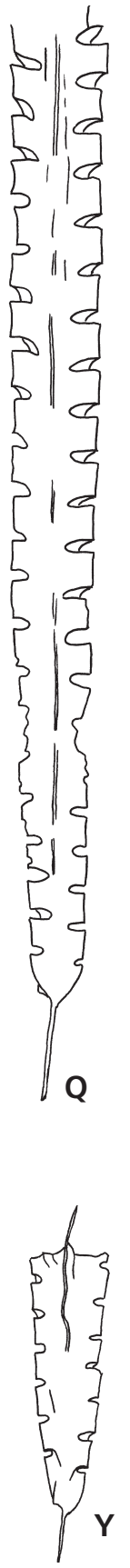

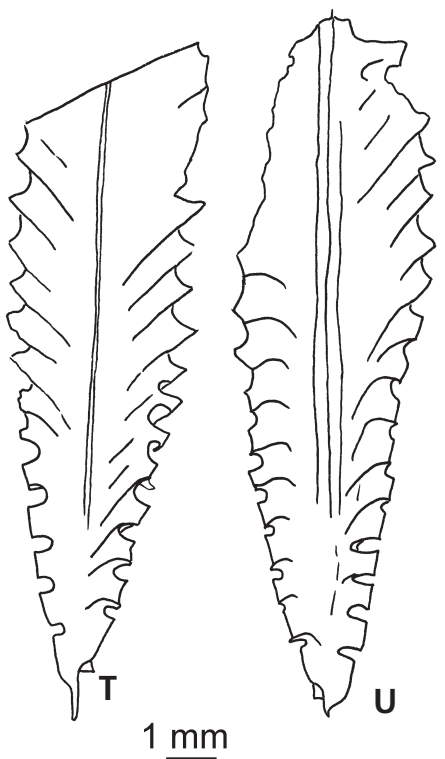

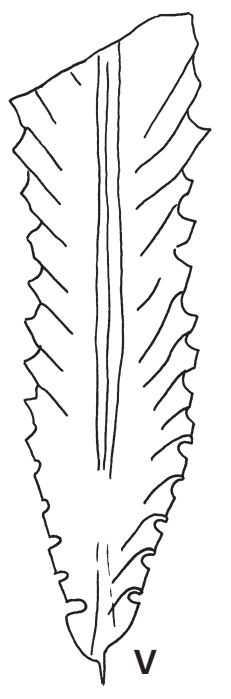

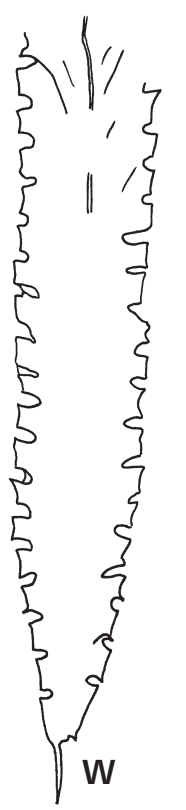

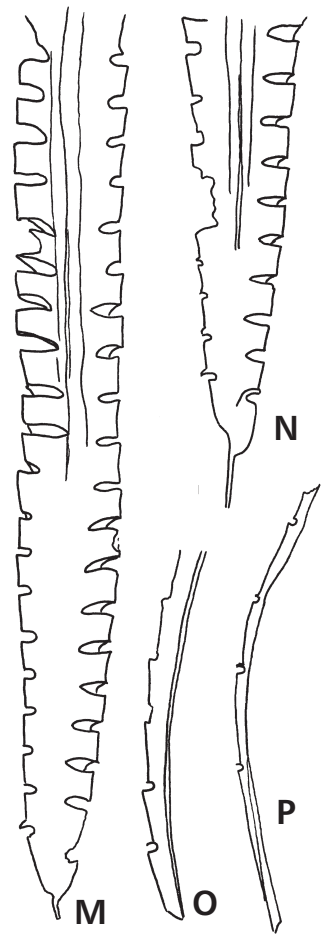

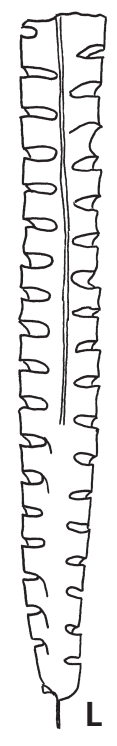

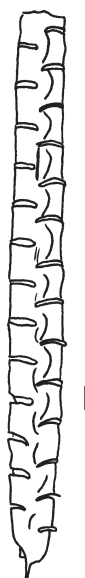
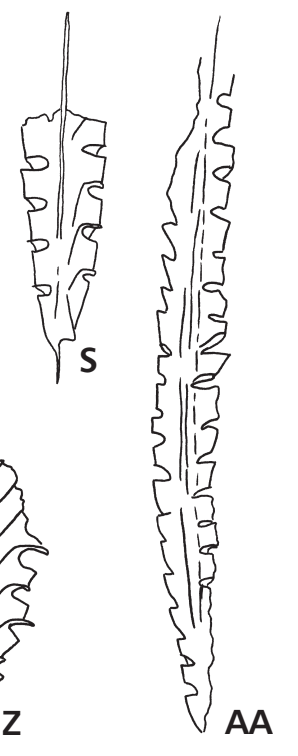

Figure 3. Graptolites from the E1-NC174 core, Murzuq Basin, Libya; core depths are quoted as they are written on the sample labels; all illustrated specimens are diagenetically flattened. • A - Normalograptus mirnyensis (Obut \& Sobolevskaya in Obut et al., 1967): BGS FOR 5570, 7249’31/2". • B - Normalograptus targuii Legrand, 2001: BGS FOR 5563, 7292’ 3”. • C - Normalograptus parvulus (H. Lapworth, 1900): BGS FOR 5564, 7292` 3”.

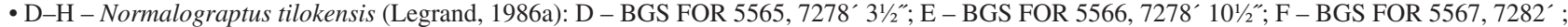

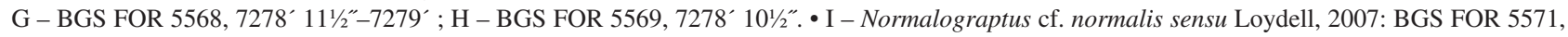
7291' • J - Normalograptus angustus (Perner, 1895): BGS FOR 5572, 7269' 111/2”。 K - Normalograptus ajjeri (Legrand, 1977): BGS FOR 5573, $7268^{\prime} 5^{\prime \prime}-7268^{\prime} 6^{\prime \prime} \cdot \bullet \mathrm{L}-$ Normalograptus medius (Törnquist, 1897): BGS FOR 5574, 7275’ 3". • M, N - Normalograptus rectangularis (McCoy, 1850): M - BGS FOR 5575, N - BGS FOR 5576, 7256’ 5". • O - Huttagraptus acinaces (Törnquist, 1899): BGS FOR 5577, 7251’ 7". • P - Huttagraptus sp.: BGS FOR 5578, 7264'10". Q - Normalograptus normalis (Lapworth, 1877): BGS FOR 5579, 7268' 5"-7268' 6". $\bullet$ R - Metaclimacograptus hughesi (Nicholson, 1869): BGS FOR 5580, 7240’3”. • S, W - Neodiplograptus africanus (Legrand, 1970): S - BGS FOR 5581, 7272' 6"-7272’ 7"; W - BGS FOR 5582, 7245' 3". • T-V - Neodiplograptus fezzanensis (Desio, 1940): T - BGS FOR 5583, 7239’ 8“; U - BGS FOR 5584, 7243’ 91/2”; V - BGS FOR 5585, 7237' 2". - X, Y - Neodiplograptus posterior (Legrand, 1970): X - BGS FOR 5586, 7243' 91/2"; Y - BGS FOR 5587, 7245' 3". •Z-Paraclimacograptus kiliani (Legrand, 1977): BGS FOR 5588, 7264’ 10”. • AA - “Glyptograptus” tariti Legrand, 1970?: BGS FOR 5589, 7263’ 8”. 
ascensus-acuminatus/Cystograptus vesiculosus Biozone boundary is consistent with all of the existing biostratigraphical data, most particularly the co-occurrence of Pa. kiliani with Huttagraptus in both Libya and Jordan. The main anomaly between the stratigraphical ranges in Libya and Jordan when compared with Algeria is that the FAD of Ne. africanus is below that of Pa. kiliani in the E1-NC174 core and in the BG-14 core, Jordan (Loydell 2007), whereas in the Oued In Djerane region the LAD of Pa. kiliani is more than $70 \mathrm{~m}$ below the FAD of Ne. africanus (Legrand 2000, fig. 3). One might perhaps argue that the Libyan and Jordanian specimens of Ne. africanus are misidentified, but if so what could they be? In the case of the lowermost E1-NC174 core specimen, it could be Ne. incommodus Legrand, 2009, the proximal end of which is similar to that of narrow specimens of $\mathrm{Ne}$. africanus. But $\mathrm{Ne}$. incommodus also has its FAD significantly (approximately $55 \mathrm{~m}$ ) above the LAD of Pa. kiliani. The Jordanian BG-14 core specimen of Ne. africanus occurring below Pa. kiliani is clearly not Ne. incommodus, however: its supragenicular walls are at a higher angle than those of the latter species and assignment to Ne. africanus seems reasonable. The most likely explanation of this apparent stratigraphical anomaly is that Ne. africanus has a longer overall stratigraphical range than indicated by Legrand (2000), that it is uncommon in the lower part of its stratigraphical range (this is supported by data from both Jordan and Libya) and that its absence from pre- $P a$. kiliani-bearing strata in Algeria may simply reflect collection failure here.

Species not recorded from the E1-NC174 core are the 'standard' biozonal indices Akidograptus ascensus Davies, 1929 and Parakidograptus acuminatus (Nicholson, 1867), neither of which has been recorded from either Libya or Algeria, and Cystograptus vesiculosus Nicholson, 1868, which has been recorded from the Ghadāmis Basin of NE Libya by Štorch \& Massa (2004). The absence of these species, and several others typical of Rhuddanian sections elsewhere in the world, is presumably due to environmental factors: temperature, salinity, oxygen level or some other factor associated with proximity to the palaeo-shoreline.

Based on the graptolites present in the E1-NC174 core and the TOC and gamma-ray curves, it is clear that the 'hot' shale in the core is of mid Rhuddanian age, occurring within the Neodiplograptus africanus Biozone. It would thus appear that this 'hot' shale is the stratigraphical equivalent of that in the Ghat-3 section, SW Libya studied by Fello et al. (2006) and in the BG-14 core in Jordan studied by Lüning et al. (2005) and Loydell et al. (2009).

\section{Conclusions}

The graptolite assemblages of the Rhuddanian of the E1-NC174 core are of low diversity and contain both ende- mic North African and cosmopolitan taxa. Three taxa are numerically dominant: Normalograptus tilokensis below, $N$. rectangularis within, and Neodiplograptus fezzanensis above the 'hot' shale. The 'hot' shale is of the same mid Rhuddanian age as 'hot' shales studied previously in the Ghat area, Libya and in southern Jordan.

\section{Acknowledgements}

Eni is thanked for funding this work and for permission to publish. Anthony Butcher kindly produced Fig. 1 and part of Fig. 2. The paper benefited from the constructive reviews of Juan Carlos Gutiérrez-Marco and Petr Štorch. This paper is a contribution to IGCP 591.

\section{References}

Butcher, A. 2009. Early Llandovery chitinozoans from Jordan. Palaeontology 52, 593-629.

DOI 10.1111/j.1475-4983.2009.00862.x

Chen, X., Fan, J.-X., Melchin, M.J. \& Mitchell, C.E. 2005. Hirnantian (latest Ordovician) graptolites from the upper Yangtze region, China. Palaeontology 48, 235-280.

DAVIES, K.A. 1929. Notes on the graptolite faunas of the Upper Ordovician and Lower Silurian. Geological Magazine 66, 1-27. DOI 10.1017/S0016756800099763

Desio, A. 1940. Fossili neosilurici del Fezzan occidentale. Annali del Museo Libico di Storia Naturale 2, 13-45.

El Chair, M., Hammann, W. \& Thiedig, F. 1985. Neue Trilobiten- und Graptolithenfunde aus den Tanezzuft-Schiefern (Llandovery, Silur) des Fezzan, Südwest-Libyen. Mitteilungen des Geologisch-Paläontologischen Institut der Universität Hamburg 59, 83-98.

Fello, N., LÜNING, S., S̆TORCH, P. \& REDFERN, J. 2006. Identification of early Llandovery (Silurian) anoxic palaeo-depressions at the western margin of the Murzuq Basin (southwest Libya), based on gamma-ray spectrometry in surface exposures. GeoArabia 11, 101-118.

JAEGER, H. 1976. Das Silur und Unterdevon vom thüringischen Typ in Sardinien und seine regionalgeologische Bedeutung. Nova Acta Leopoldina, Neue Folge 45, 263-299.

Koren', T.N., Ahlberg, P. \& Nielsen, A.T. 2003. The postpersculptus and pre-ascensus graptolite fauna in Scania, south-western Sweden: Ordovician or Silurian?, 133-138. In Ortega, G. \& Aceñolaza, G.F. (eds) Proceedings of the $7^{\text {th }}$ International Graptolite Conference \& Field Meeting of the International Subcommission on Silurian Stratigraphy. 181 pp. Serie Correlación Geológica 18, Instituto Superior de Correlación Geológica (INSUGEO), Tucumán.

Lapworth, C. 1877. On the graptolites of County Down. Proceedings of the Belfast Naturalists' Field Club 1876-1877, $125-148$.

LAPWORTH, H. 1900. The Silurian sequence of Rhayader. Quarterly Journal of the Geological Society of London 56, 67-137. DOI 10.1144/GSL.JGS.1900.056.01-04.09

LEGRAND, P. 1969. Découverte de graptolites entre Gara Djebilet 
et Aouinet bel Egra (Synéclise de Tindouf - Sahara Algérien). Bulletin de la Société d'Histoire Naturelle de l'Afrique du Nord 59, 1-12.

Legrand, P. 1970. Les couches a Diplograptus du Tassili de Tarit (Ahnet, Sahara algérien). Bulletin de la Société d'Histoire Naturelle de l'Afrique du Nord 60, 3-58.

Legrand, P. 1977. Contribution à l'étude des graptolites du Llandoverien inferieur de l'Oued In Djerane (Tassili N'Ajjer oriental, Sahara algérien). Bulletin de la Société d'Histoire Naturelle de l'Afrique du Nord 67, 141-196.

LEgRAND, P. 1978. Sur la presence de structures tubulaires à l'intérieur des thèques de Diplograptus fezzanensis A. Desio. Comptes Rendus de l'Académie des Sciences, Paris, Série D 286, 387-390.

LEgRAND, P. 1979. Premières observations sur des structures tubulaires à l'intérieur des thèques de Diplograptus fezzanensis Desio. Essai d'interprétation. Acta Palaeontologica Polonica 24, 107-120.

LEGRAND, P. 1986a. The Silurian graptolites of Oued In Djerane: a study of populations at the Ordovician-Silurian boundary, 145-163. In Hughes, C.P. \& Rickards, R.B. (eds) Palaeoecology and biostratigraphy of graptolites, Geological Society Special Publication 20, 1-277.

LEGRAND, P. 1986b. New data on tubular structures located within diplograptid rhabdosomes and in the surrounding sediment. Hercynica 2, 111-123.

LEGRAND, P. 1995. A propos d'un niveau à Neodiplograptus dans le Silurien inférieur à l'est de Ouallene, Asejrad (Sahara algérien). Implications stratigraphiques et paléogéographiques. 118 Congrès national des Sociétés historiques et scientifiques, 4ème colloque sur la Géologie africaine, Pau, 409-424.

Legrand, P. 1998. On the causes of extinction: the case of the genus Petalolithus (auctorum) from the Algerian Sahara. Temas Geológico-Mineros ITGE 23, 208-211.

LEGRAND, P. 1999. Approche stratigraphique de l'Ordovicien terminal et du Silurien inferieur du Sahara algerien par l'étude des Diplograptides (Graptolites). 892 pp. Unpublished Ph.D. thesis, Université Michel de Montaigne - Bordeaux III, Institut EGID Bordeaux III.

LEGRAND, P. 2000. Une région de référence pour la limite Ordovicien-Silurien: l'Oued In Djerane, Sahara algérien. Comptes Rendus de l'Académie des Sciences, Paris, Sciences de la Terre et des Planètes 330, 61-66.

Legrand, P. 2001. La faune graptolitique de la région d'In Azaoua (Tassili Oua-n-Ahaggar, confines algéro-nigériens). Annales de la Société Géologique du Nord (Série 2) 8, $137-158$.

Legrand, P. 2002. La Formation des Argiles de Tedjert (?Ordovicien terminal-Silurien inferieur) au Tassili Oua-n-Ahaggar oriental (Sahara algerien) et sa faune graptolitique. Annales de la Société Géologique du Nord (Série 2) 9, 215-229.

LEgRAND, P. 2003. Silurian stratigraphy and paleogeography of the northern African margin of Gondwana. New York State Museum Bulletin 493, 59-104.

Legrand, P. 2009. Faunal specifity, endemism and paleobiogeography: the post-glacial (Hirnantian-early Rhuddanian) graptolite fauna of the North-African border of Gondwana: a case study. Bulletin de la Société Géologique de France 180, 353-367. DOI 10.2113/gssgfbull.180.4.353
LOYDELL, D.K. 2007. Graptolites from the Upper Ordovician and lower Silurian of Jordan. Special Papers in Palaeontology 78, $1-66$.

Loydell, D.K., Butcher, A., FrÝda, J., LÜNING, S. \& Fowler, M. 2009. Lower Silurian "hot shales" in Jordan: a new depositional model. Journal of Petroleum Geology 32, 261-270. DOI 10.1111/j.1747-5457.2009.00447.x

Lüning, S., Craig, J., Fitches, B., Mayouf, J., Busrewil, A., El Dieb, M., Gammudi, A., Loydell, D. \& Mcllroy, D. 1999. Re-evaluation of the petroleum potential of the Kufra Basin SE Libya, NE Chad): does the source rock barrier fall? Marine and Petroleum Geology 16, 693-718.

DOI 10.1016/S0264-8172(99)00013-6

LÜning, S., Craig, J., Loydell, D.K., ŠTorch, P. \& Fitches, B. 2000. Lower Silurian 'hot shales' in North Africa and Arabia: regional distribution and depositional model. Earth-Science Reviews 49, 121-200.

DOI 10.1016/S0012-8252(99)00060-4

LÜning, S., Kolonic, S., Loydell, D.K. \& CRAig, J. 2003. Reconstruction of the original organic richness in weathered Silurian shale outcrops (Murzuq and Kufra basins, southern Libya). GeoArabia 8, 299-308.

LÜning, S., Shahin, Y.M., Loydell, D., Al-Rabi, H.T., Masri, A., TARAwneh, B. \& Kolonic, S. 2005. Anatomy of a worldclass source-rock: distribution and depositional model of Silurian organic-rich shales in Jordan and implications for hydrocarbon potential. AAPG Bulletin 89, 1397-1427.

DOI 10.1306/05250505014

MaURY, C.J. 1929. Uma zona de Graptolitos do Llandovery inferior no Rio Trombetas, Estado do Pará, Brasil. Serviço Geologico e Mineralogico do Brasil, Monographia 7, 6-45.

McCoy, F. 1850. On some new genera and species of Silurian Radiata in the collection of the University of Cambridge. Annals and Magazine of Natural History 2(6), 270-290.

Nicholson, H.A. 1867. On some fossils from the Lower Silurian rocks of the South of Scotland. Geological Magazine 1(4), 107-113. DOI 10.1017/S0016756800205293

Nicholson, H.A. 1868. On the nature and zoological position of the Graptolitidae. Annals and Magazine of Natural History 4(1), 55-61. DOI 10.1080/00222936808695638

Nicholson, H.A. 1869. On some new species of graptolites. Annals and Magazine of Natural History 4(4), 231-242. DOI 10.1080/00222936908696041

Obut, A.M., Sobolevskaya, R.F. \& Nikolaev, A.A. 1967. Graptolites and stratigraphy of the lower Silurian along the margins of the Kolyma massif. 164 pp. Akademiya Nauk SSR, Sibirskoje Otdelenie Institut Geologii i Geofiziki. Ministerstvo Geologii SSSR, Nauchno-Issledovatel'sky Institut Geologii Arktiki. [in Russian]

PARIZEK, A., KLen, L. \& RöHlich, P. 1984. Explanatory booklet for the Geological Map of Libya 1:250,000 Sheet Idri, NG33-1. 108 pp. Industrial Research Centre, Tripoli.

Perner, J. 1895. Études sur les Graptolites de Bohême. IIième Partie. Monographie des Graptolites de l'Étage D. 31 pp. Raimond Gerhard, Prague.

S̆тоRсн, P. 1983. The genus Diplograptus (Graptolithina) from the lower Silurian of Bohemia. Věstník Ústředního ústavu geologického 58, 159-170.

ŠToRCH, P. \& MASSA, D. 2004. Biostratigraphy, correlation, envi- 
ronmental and biogeographic interpretations of the lower Silurian graptolite faunas of Libya, 237-251. In SALEM, M.J. \& Oun, K.M. (eds) The geology of northwest Libya, Vol. 1, Sedimentary basins of Libya - Second symposium. 339 pp. Earth Science Society of Libya, Tripoli.

Šтorch, P. \& MASSA, D. 2006. Middle Llandovery (Aeronian) graptolites of the western Murzuq Basin and Al Qarqaf Arch region, south-west Libya. Palaeontology 49, 83-112. DOI 10.1111/j.1475-4983.2005.00530.x

Štorch, P. \& MASSA, D. 2007. Middle Telychian (upper Llandovery, Silurian) graptolites from boreholes of northwestern Libya: their biostratigraphic significance and palaeo- geographical implication. Geobios 40, 535-540.

DOI 10.1016/j.geobios.2006.06.001

TÖRNQUIST, S.L. 1897. On the Diplograptidæ and Heteroprionidæ of the Scanian Rastrites-Beds. Lunds Universitets Arsskrift 33, $1-24$.

TöRnQuist, S.L. 1899. Researches into the Monograptidae of the Scanian Rastrites Beds. Lunds Universitets Arsskrift 35, 1-26.

Underwood, C.J., Deynoux, M. \& Ghienne, J.-F. 1998. High palaeolatitude (Hodh, Mauritania) recovery of graptolite faunas after the Hirnantian (end Ordovician) extinction event. Palaeogeography, Palaeoclimatology, Palaeoecology 142, 91-105. DOI 10.1016/S0031-0182(98)00070-4
Table 1. Measurements of rhabdosome dorso-ventral width (DVW) and two thecae repeat distance (2TRD) in Normalograptus tilokensis (Legrand, 1986a) from the E1-NC174 core.

\begin{tabular}{|c|c|c|c|c|c|c|c|}
\hline Depth & & Th1 $1^{1}$ & $\mathrm{Th} 2^{1}$ & $\mathrm{Th}^{1}{ }^{1}$ & Th5 ${ }^{1}$ & Th10 ${ }^{1}$ & Th1 $15^{1}$ \\
\hline \multirow[t]{2}{*}{$7276^{\prime} 4^{\prime \prime}$} & DVW & 1.0 & 1.2 & 1.45 & 1.75 & & \\
\hline & 2TRD & & 1.6 & 1.7 & 1.8 & & \\
\hline \multirow[t]{2}{*}{$7276^{\prime} 4^{\prime \prime}$} & DVW & 0.9 & 1.2 & 1.4 & 1.75 & & \\
\hline & 2TRD & & 1.6 & 1.6 & 1.85 & & \\
\hline \multirow[t]{2}{*}{$7276^{\prime} 4^{\prime \prime}$} & DVW & 0.9 & 1.1 & 1.35 & - & 1.6 & 1.5 \\
\hline & 2TRD & & 1.7 & 1.7 & - & 1.85 & 1.95 \\
\hline \multirow[t]{2}{*}{$7278^{\prime} 3 \frac{1 / 2 "}{2}$} & DVW & - & 1.2 & 1.4 & 1.85 & 2.3 & \\
\hline & 2TRD & & 1.75 & 1.9 & 1.8 & 2.05 & \\
\hline \multirow[t]{2}{*}{$7278^{\prime} 3 \frac{1}{2 \prime \prime}$} & DVW & 1.0 & 1.3 & 1.5 & 2.0 & 2.1 & 2.25 \\
\hline & 2TRD & & 1.7 & 1.65 & 1.65 & 1.65 & 1.6 \\
\hline \multirow[t]{2}{*}{$7278^{\prime} 10^{1 / 2 "}$} & DVW & 0.95 & 1.2 & 1.5 & 2.0 & 2.65 & \\
\hline & 2TRD & & 1.9 & 1.7 & 1.8 & 1.7 & \\
\hline \multirow[t]{2}{*}{$7278^{\prime} 10^{1 / 2 "}$} & DVW & 1.15 & 1.45 & 1.65 & 2.05 & 2.25 & \\
\hline & 2TRD & & 1.6 & 1.6 & 1.7 & 1.75 & \\
\hline \multirow[t]{2}{*}{$7278^{\prime} 11 \frac{1}{2} 2^{\prime \prime}$} & DVW & 0.9 & 1.1 & 1.3 & 1.75 & & \\
\hline & 2TRD & & 1.8 & 1.9 & 2.0 & & \\
\hline \multirow[t]{2}{*}{$7282^{\prime}$} & DVW & 0.95 & 1.2 & 1.3 & 1.5 & & \\
\hline & 2TRD & & 1.6 & 1.6 & 1.6 & & \\
\hline \multirow[t]{2}{*}{$7284^{\prime} 4^{\prime \prime}$} & DVW & 1.1 & 1.4 & 1.65 & 1.8 & & \\
\hline & 2TRD & & 1.65 & 1.75 & 1.65 & & \\
\hline \multirow[t]{2}{*}{$7288^{\prime} 1^{\prime \prime}$} & DVW & 0.9 & 1.2 & 1.4 & 1.5 & 1.65 & 1.7 \\
\hline & 2TRD & & 1.45 & 1.55 & 1.55 & 1.75 & 1.75 \\
\hline \multirow[t]{2}{*}{$7292^{\prime} 11^{\prime \prime}$} & DVW & 0.95 & 1.1 & 1.35 & 1.7 & 1.8 & \\
\hline & 2TRD & & 1.65 & 1.65 & 1.75 & 1.85 & \\
\hline
\end{tabular}

Table 2. Measurements of rhabdosome dorso-ventral width (DVW) and two thecae repeat distance (2TRD) in Normalograptus rectangularis (McCoy, 1850) from the E1-NC174 core.

\begin{tabular}{|c|c|c|c|c|c|c|c|c|}
\hline Depth & & Th1 ${ }^{1}$ & $\mathrm{Th} 2^{1}$ & $\mathrm{Th}^{1}{ }^{1}$ & $\mathrm{Th}^{1}$ & Th10 1 & Th1 $15^{1}$ & Th201 \\
\hline \multirow[t]{2}{*}{$7248^{\prime} 21^{\prime \prime}$} & DVW & 0.85 & 0.95 & 1.15 & 1.4 & 1.75 & 1.9 & \\
\hline & 2TRD & & 1.7 & 1.7 & 1.7 & 1.8 & 1.6 & \\
\hline \multirow[t]{2}{*}{$7250^{\prime} 4^{\prime \prime}$} & DVW & 0.8 & 1.0 & 1.2 & 1.55 & & & \\
\hline & 2TRD & & 1.5 & 1.55 & & & & \\
\hline \multirow[t]{2}{*}{$7252^{\prime} 6^{\prime \prime}$} & DVW & 0.8 & 0.95 & 1.0 & 1.25 & & & \\
\hline & 2TRD & & 1.6 & 1.65 & 1.4 & & & \\
\hline \multirow[t]{2}{*}{$7252^{\prime} 6^{\prime \prime}$} & DVW & 0.75 & 0.9 & - & 1.2 & & & \\
\hline & 2TRD & & 1.5 & 1.45 & 1.5 & & & \\
\hline \multirow[t]{2}{*}{$7255^{\prime} 7^{\prime \prime}$} & DVW & 0.8 & 0.85 & 1.05 & 1.45 & 2.0 & & \\
\hline & 2TRD & & 1.4 & 1.35 & 1.6 & & & \\
\hline \multirow[t]{2}{*}{$7256^{\prime} 5^{\prime \prime}$} & DVW & 0.9 & 1.2 & 1.35 & 1.65 & 2.2 & & \\
\hline & 2TRD & & 1.5 & 1.45 & 1.55 & 1.65 & & \\
\hline \multirow[t]{2}{*}{$7256^{\prime} 5^{\prime \prime}$} & DVW & 0.95 & 1.25 & 1.4 & 1.6 & 2.0 & 2.05 & 1.95 \\
\hline & 2TRD & & - & 1.55 & 1.55 & 1.65 & 1.65 & 1.65 \\
\hline \multirow[t]{2}{*}{$7256^{\prime} 5^{\prime \prime}$} & DVW & 0.85 & 1.15 & 1.25 & 1.6 & 2.15 & 2.35 & 2.4 \\
\hline & 2TRD & & 1.7 & 1.55 & 1.4 & - & 1.4 & 1.5 \\
\hline \multirow[t]{2}{*}{$7257^{\prime} 1^{\prime \prime}$} & DVW & 0.95 & 1.25 & 1.45 & 1.9 & 2.5 & 3.1 & 2.75 \\
\hline & 2TRD & & 1.6 & 1.6 & - & - & 1.5 & 1.6 \\
\hline \multirow[t]{2}{*}{$7263^{\prime} 1^{\prime \prime}$} & DVW & 0.9 & 1.0 & 1.1 & 1.25 & & & \\
\hline & 2TRD & & 1.5 & 1.6 & 1.7 & & & \\
\hline \multirow[t]{2}{*}{$7266^{\prime} 9^{\prime \prime}$} & DVW & 0.9 & 1.15 & - & 1.5 & & & \\
\hline & 2TRD & & 1.7 & 1.7 & 1.8 & & & \\
\hline \multirow[t]{2}{*}{$7267^{\prime} 11^{\prime \prime}$} & DVW & 0.9 & 1.15 & 1.3 & 1.6 & & & \\
\hline & 2TRD & & 1.6 & 1.6 & 1.6 & & & \\
\hline \multirow[t]{2}{*}{$7267^{\prime} 11^{\prime \prime}$} & DVW & 0.85 & 1.0 & 1.1 & 1.3 & 1.55 & & \\
\hline & 2TRD & & 1.7 & 1.7 & 1.7 & 1.85 & & \\
\hline \multirow[t]{2}{*}{$7268^{\prime} 11^{\prime \prime}$} & DVW & 0.85 & 1.0 & 1.15 & 1.35 & 1.5 & & \\
\hline & 2TRD & & 1.5 & - & - & 1.8 & & \\
\hline
\end{tabular}


Table 3. Measurements of rhabdosome dorso-ventral width (DVW) and two thecae repeat distance (2TRD) in Neodiplograptus posterior (Legrand, 1970) from the E1-NC174 core.

\begin{tabular}{|c|c|c|c|c|c|c|c|}
\hline Depth & & Th1 $1^{1}$ & Th2 $2^{1}$ & $\mathrm{Th}^{1}$ & $\mathrm{Th} 5^{1}$ & Th10 1 & Th$_{15^{1}}$ \\
\hline \multirow[t]{2}{*}{$7237^{\prime} 2^{\prime \prime}$} & DVW & 1.0 & 1.3 & 1.5 & 1.75 & & \\
\hline & 2TRD & & 1.7 & 1.8 & 1.75 & & \\
\hline \multirow[t]{2}{*}{$7241^{\prime} 4^{\prime \prime}$} & DVW & 1.0 & 1.35 & 1.6 & 1.85 & 2.0 & 1.9 \\
\hline & 2TRD & & 1.6 & - & 1.55 & 1.75 & 1.8 \\
\hline \multirow[t]{2}{*}{$7243^{\prime} 9^{1 / 2} 2^{\prime \prime}$} & DVW & 1.05 & 1.45 & 1.4 & 1.75 & 1.5 & 1.8 \\
\hline & 2TRD & & 1.5 & 1.35 & 1.45 & 1.8 & 2.15 \\
\hline \multirow[t]{2}{*}{$7245^{\prime} 3^{\prime \prime}$} & DVW & 0.85 & 1.05 & 1.35 & 1.45 & & \\
\hline & 2TRD & & 1.55 & 1.6 & 1.45 & & \\
\hline \multirow[t]{2}{*}{$7248^{\prime} 2 \frac{1}{2 \prime \prime}$} & DVW & 0.95 & 1.1 & 1.25 & 1.5 & & \\
\hline & 2TRD & & 1.5 & 1.5 & 1.5 & & \\
\hline
\end{tabular}

Table 4. Measurements of rhabdosome dorso-ventral width (DVW) and two thecae repeat distance (2TRD) in various graptolite species from the E1-NC174 core.

\begin{tabular}{|c|c|c|c|c|c|c|c|}
\hline Species & Depth & $\mathrm{Th}^{1}{ }^{1}$ & $\mathrm{Th} 2^{1}$ & $\mathrm{Th}^{1}{ }^{1}$ & $\mathrm{Th} 5^{1}$ & Th10 & ${ }^{1}$ Th15 1 \\
\hline \multirow[t]{2}{*}{ Me. hughesi } & $7240^{\prime} 3^{\prime \prime}$ & DVW 0.8 & 0.9 & 1.0 & 1.05 & 1.05 & \\
\hline & & 2TRD & 1.25 & 1.4 & 1.5 & 1.5 & \\
\hline \multirow[t]{2}{*}{ Paracl. kiliani } & $i 7264^{\prime} 10^{\prime \prime}$ & DVW 1.15 & 1.7 & 2.4 & & & \\
\hline & & 2TRD & 1.45 & 1.45 & & & \\
\hline \multirow[t]{2}{*}{ Paracl. kiliani } & $i 7269^{\prime} 11^{1}{ }^{\prime \prime}$ & DVW 0.9 & 1.5 & 1.8 & 2.3 & & \\
\hline & & 2TRD & 1.5 & 1.5 & 1.55 & & \\
\hline \multirow[t]{2}{*}{ "G." tariti? } & $7263^{\prime} 8^{\prime \prime}$ & DVW - & 0.9 & 1.1 & 1.3 & 1.4 & \\
\hline & & 2TRD & - & 1.45 & 1.5 & & \\
\hline \multirow[t]{2}{*}{ "G." tariti? } & $7263^{\prime} 8^{\prime \prime}$ & DVW - & - & - & 1.1 & 1.4 & 1.5 \\
\hline & & 2TRD & 1.2 & 1.2 & 1.35 & 1.25 & 1.35 \\
\hline
\end{tabular}

Table 5. Measurements of rhabdosome dorso-ventral width (DVW) and two thecae repeat distance (2TRD) in Neodiplograptus africanus (Legrand, 1970) from the E1-NC174 core.

\begin{tabular}{|c|c|c|c|c|c|c|c|}
\hline Depth & & $\mathrm{Th}^{1}{ }^{1}$ & Th2 ${ }^{1}$ & Th3 ${ }^{1}$ & Th5 ${ }^{1}$ & Th10 ${ }^{1}$ & $\mathrm{Th}_{15^{1}}$ \\
\hline \multirow[t]{2}{*}{$7240^{\prime} 3^{\prime \prime}$} & DVW & 1.0 & 1.1 & 1.4 & 1.85 & 2.35 & 2.7 \\
\hline & 2TRD & & 1.65 & 1.65 & 1.75 & 1.65 & \\
\hline \multirow[t]{2}{*}{$7245^{\prime} 3^{\prime \prime}$} & DVW & 1.0 & 1.4 & 1.7 & 2.15 & 2.5 & 2.5 \\
\hline & 2TRD & & 1.45 & 1.4 & 1.4 & 1.4 & 1.45 \\
\hline \multirow[t]{2}{*}{$7245^{\prime} 3^{\prime \prime}$} & DVW & 1.05 & 1.4 & 1.65 & 2.0 & & \\
\hline & 2TRD & & 1.5 & 1.3 & 1.5 & & \\
\hline \multirow[t]{2}{*}{$7246^{\prime} 5^{\prime \prime}$} & DVW & 0.95 & 1.25 & 1.6 & 1.95 & - & \\
\hline & 2TRD & & 1.3 & 1.3 & 1.4 & 1.35 & \\
\hline \multirow[t]{2}{*}{$7247^{\prime} 3^{\prime \prime}$} & DVW & 1.0 & 1.25 & 1.6 & 2.05 & 2.35 & \\
\hline & 2TRD & & 1.6 & 1.6 & 1.4 & 1.4 & \\
\hline \multirow[t]{2}{*}{$7247^{\prime} 3^{\prime \prime}$} & DVW & 0.9 & 1.35 & 1.65 & 1.9 & & \\
\hline & 2TRD & & 1.45 & 1.45 & & & \\
\hline \multirow[t]{2}{*}{$7272^{\prime} 6^{\prime \prime}$} & DVW & 0.95 & 1.3 & 1.5 & & & \\
\hline & 2TRD & & 1.7 & 1.6 & & & \\
\hline
\end{tabular}

Table 6. Measurements of rhabdosome dorso-ventral width (DVW) and two thecae repeat distance (2TRD) in Neodiplograptus fezzanensis (Desio, 1940) from the E1-NC174 core.

\begin{tabular}{|c|c|c|c|c|c|c|c|}
\hline Depth & & $\mathrm{Th}^{1}{ }^{1}$ & $\mathrm{Th} 2^{1}$ & Th3 ${ }^{1}$ & $\mathrm{Th}^{1}$ & Th10 ${ }^{1}$ & $\operatorname{Th} 15^{1}$ \\
\hline \multirow[t]{2}{*}{$7237^{\prime} 2^{\prime \prime}$} & DVW & 1.1 & 1.7 & 2.1 & 2.8 & 3.6 & \\
\hline & 2TRD & & 1.45 & 1.5 & 1.35 & & \\
\hline \multirow[t]{2}{*}{$7237^{\prime} 2^{\prime \prime}$} & DVW & 1.25 & 1.65 & 2.1 & 2.9 & 3.1 & \\
\hline & 2TRD & & 1.3 & 1.4 & 1.35 & 1.6 & \\
\hline \multirow[t]{2}{*}{$7238^{\prime} 4^{\prime \prime}$} & DVW & 1.05 & 1.6 & 1.95 & 2.75 & & \\
\hline & 2TRD & & 1.45 & 1.45 & 1.45 & & \\
\hline \multirow[t]{2}{*}{$7238^{\prime} 4^{\prime \prime}$} & DVW & 1.05 & 1.55 & - & 2.25 & & \\
\hline & 2TRD & & 1.4 & 1.45 & 1.5 & & \\
\hline \multirow[t]{2}{*}{$7239^{\prime} 6^{\prime \prime}$} & DVW & 1.0 & 1.3 & - & 2.25 & & \\
\hline & 2TRD & & 1.55 & 1.5 & 1.5 & & \\
\hline \multirow[t]{2}{*}{$7239^{\prime} 8^{\prime \prime}$} & DVW & 1.0 & 1.55 & 1.8 & 2.5 & 3.65 & \\
\hline & 2TRD & & 1.6 & 1.75 & 1.5 & & \\
\hline \multirow[t]{2}{*}{$7239^{\prime} 8^{\prime \prime}$} & DVW & 1.1 & 1.75 & 2.25 & 2.5 & & \\
\hline & 2TRD & & 1.5 & 1.45 & 1.15 & & \\
\hline \multirow[t]{2}{*}{$7239^{\prime} 8^{\prime \prime}$} & DVW & 1.0 & 1.75 & 2.35 & 2.9 & - & 3.5 \\
\hline & 2TRD & & 1.7 & 1.7 & 1.65 & - & \\
\hline \multirow[t]{2}{*}{$7240^{\prime} 3^{\prime \prime}$} & DVW & 1.0 & 1.3 & 1.65 & 2.05 & 3.0 & 3.55 \\
\hline & 2TRD & & 1.6 & 1.7 & 1.6 & 1.65 & \\
\hline \multirow[t]{2}{*}{$7240^{\prime} 3^{\prime \prime}$} & DVW & 0.95 & 1.25 & 1.45 & 2.4 & & \\
\hline & 2TRD & & 1.85 & 1.8 & - & & \\
\hline \multirow[t]{2}{*}{$7240^{\prime} 3^{\prime \prime}$} & DVW & 1.0 & 1.45 & 1.9 & 2.6 & - & \\
\hline & 2TRD & & 1.5 & 1.45 & 1.45 & 1.65 & \\
\hline \multirow[t]{2}{*}{$7240^{\prime} 3^{\prime \prime}$} & DVW & 1.1 & 1.5 & 1.75 & 2.3 & 3.4 & \\
\hline & 2TRD & & 1.4 & 1.4 & 1.5 & 1.5 & \\
\hline \multirow[t]{2}{*}{$7240^{\prime} 3^{\prime \prime}$} & DVW & 0.95 & 1.25 & 1.5 & 2.0 & & \\
\hline & 2TRD & & 1.75 & 1.85 & 1.55 & & \\
\hline \multirow[t]{2}{*}{$7240^{\prime} 3^{\prime \prime}$} & DVW & 1.0 & 1.25 & 1.65 & 2.1 & 3.0 & \\
\hline & 2TRD & & 1.65 & 1.75 & 1.8 & & \\
\hline \multirow[t]{2}{*}{$7240^{\prime} 3^{\prime \prime}$} & DVW & 0.9 & 1.2 & - & 2.4 & 3.0 & 3.15 \\
\hline & 2TRD & & 1.75 & 1.6 & 1.7 & - & 1.6 \\
\hline \multirow[t]{2}{*}{$7240^{\prime} 3^{\prime \prime}$} & DVW & 1.05 & 1.45 & 1.85 & 2.3 & 2.9 & \\
\hline & 2TRD & & 1.6 & 1.6 & 1.45 & - & \\
\hline \multirow[t]{2}{*}{$7240^{\prime} 3^{\prime \prime}$} & DVW & 1.05 & 1.55 & 2.0 & 2.45 & & \\
\hline & 2TRD & & 1.65 & 1.65 & 1.7 & & \\
\hline \multirow[t]{2}{*}{$7240^{\prime} 3^{\prime \prime}$} & DVW & 1.1 & 1.5 & 1.75 & 2.5 & 2.9 & \\
\hline & 2TRD & & 1.6 & 1.6 & - & & \\
\hline \multirow[t]{2}{*}{$7240^{\prime} 3^{\prime \prime}$} & DVW & 1.0 & 1.25 & 1.75 & 2.1 & & \\
\hline & 2TRD & & 1.65 & 1.55 & 1.65 & & \\
\hline \multirow[t]{2}{*}{$7241^{\prime} 4^{\prime \prime}$} & DVW & 1.1 & 1.65 & 2.0 & 2.9 & 3.65 & \\
\hline & 2TRD & & 1.75 & 1.5 & 1.4 & 1.4 & \\
\hline \multirow[t]{2}{*}{$7242^{\prime} 7^{\prime \prime}$} & DVW & 0.95 & 1.35 & 1.55 & 2.2 & - & - \\
\hline & 2TRD & & 1.45 & 1.45 & 1.55 & - & 1.4 \\
\hline \multirow[t]{2}{*}{$7243^{\prime} 91^{\prime \prime \prime}$} & DVW & 1.0 & 1.5 & 1.9 & 2.35 & 3.5 & \\
\hline & 2TRD & & 1.5 & 1.35 & 1.45 & - & \\
\hline
\end{tabular}


Table 7. Measurements of rhabdosome dorso-ventral width (DVW) and two thecae repeat distance (2TRD) in various Normalograptus species from the E1-NC174 core.

\begin{tabular}{|c|c|c|c|c|c|c|c|c|c|}
\hline Species & Depth & & $\mathrm{Th}^{1}{ }^{1}$ & $\mathrm{Th} 2^{1}$ & $\mathrm{Th}^{1}$ & $\mathrm{Th} 5^{1}$ & Th10 1 & Th1 $15^{1}$ & Th2 $20^{1}$ \\
\hline \multirow[t]{2}{*}{ N. ajjeri } & $7268^{\prime} 5^{\prime \prime}$ & DVW & 0.9 & 1.1 & 1.15 & 1.4 & 1.4 & & \\
\hline & & 2TRD & & 1.3 & 1.35 & 1.45 & 1.55 & & \\
\hline \multirow[t]{2}{*}{ N. ajjeri } & $7268^{\prime} 5^{\prime \prime}$ & DVW & 0.85 & 1.0 & 1.0 & 1.25 & & & \\
\hline & & 2TRD & & - & 1.55 & 1.65 & & & \\
\hline \multirow[t]{2}{*}{ N. ajjeri } & $7271^{\prime} 8^{\prime \prime}$ & DVW & 0.9 & 1.05 & 1.1 & 1.1 & & & \\
\hline & & 2TRD & & 1.65 & - & - & & & \\
\hline \multirow[t]{2}{*}{ N. ajjeri } & $7274^{\prime} 6^{\prime \prime}$ & DVW & 1.0 & 1.3 & 1.5 & 1.6 & 1.55 & 1.6 & \\
\hline & & 2TRD & & 1.65 & 1.65 & 1.8 & 1.7 & 1.9 & \\
\hline \multirow[t]{2}{*}{ N. ajjeri } & $7275^{\prime} 3^{\prime \prime}$ & DVW & 1.0 & 1.15 & 1.25 & - & 1.4 & 1.35 & \\
\hline & & 2TRD & & 1.4 & 1.3 & 1.4 & 1.6 & & \\
\hline \multirow[t]{2}{*}{ N. ajjeri } & $7284^{\prime} 9^{\prime \prime}$ & DVW & 1.05 & 1.25 & 1.35 & 1.5 & 1.55 & 1.4 & 1.45 \\
\hline & & 2TRD & & 1.5 & 1.6 & 1.7 & 1.7 & 1.85 & 1.95 \\
\hline \multirow[t]{2}{*}{$N$. angustus } & $7269^{\prime} 11 \frac{1}{1}{ }^{\prime \prime}$ & DVW & - & - & 0.95 & 1.0 & 1.0 & & \\
\hline & & 2TRD & & - & - & 1.9 & & & \\
\hline \multirow[t]{2}{*}{ N. medius } & $7269^{\prime} 1^{\prime \prime}$ & DVW & 0.9 & 1.05 & 1.15 & 1.5 & 1.6 & 1.85 & \\
\hline & & 2TRD & & 1.5 & - & - & 1.8 & & \\
\hline \multirow[t]{2}{*}{ N. medius } & $7275^{\prime} 3^{\prime \prime}$ & DVW & 0.9 & 1.15 & 1.3 & 1.5 & 1.65 & 1.7 & \\
\hline & & 2TRD & & 1.4 & 1.45 & 1.45 & 1.55 & 1.6 & \\
\hline \multirow[t]{2}{*}{ N. normalis } & $7268^{\prime} 5^{\prime \prime}$ & DVW & 0.95 & 1.05 & 1.2 & 1.45 & 1.55 & 1.8 & 1.85 \\
\hline & & 2TRD & & 1.7 & - & - & - & 1.95 & 1.9 \\
\hline \multirow[t]{2}{*}{ N. normalis } & $7276^{\prime} 4^{\prime \prime}$ & DVW & 0.95 & - & - & 1.55 & & & \\
\hline & & 2TRD & & 1.55 & 1.6 & 1.75 & & & \\
\hline \multirow[t]{2}{*}{ N. normalis } & $7284^{\prime} 9^{\prime \prime}$ & DVW & 1.05 & 1.35 & 1.5 & 1.8 & 2.0 & & \\
\hline & & 2TRD & & 1.5 & 1.45 & 1.6 & & & \\
\hline \multirow[t]{2}{*}{ N. normalis } & $7284^{\prime} 9^{\prime \prime}$ & DVW & 1.15 & 1.4 & 1.55 & 1.75 & 2.05 & & \\
\hline & & 2TRD & & 1.55 & 1.6 & 1.6 & 1.9 & & \\
\hline \multirow[t]{2}{*}{$N$. cf. normalis } & $7255^{\prime} 7^{\prime \prime}$ & DVW & 0.95 & 1.1 & 1.25 & 1.4 & 1.1 & & \\
\hline & & 2TRD & & 1.55 & 1.5 & 1.55 & 1.6 & & \\
\hline \multirow[t]{2}{*}{ N. cf. normalis } & $7272^{\prime} 6^{\prime \prime}$ & DVW & 1.0 & 1.25 & 1.4 & 1.75 & 1.7 & & \\
\hline & & 2TRD & & 1.7 & 1.7 & 1.6 & 1.7 & & \\
\hline \multirow[t]{2}{*}{ N. cf. normalis } & $7291^{\prime}$ & DVW & 1.25 & 1.4 & 1.55 & 1.75 & 1.75 & & \\
\hline & & 2TRD & & 1.5 & 1.5 & $1.55\left(5^{2}\right)$ & & & \\
\hline \multirow[t]{2}{*}{ N. parvulus } & $7273^{\prime} 4^{\prime \prime}$ & DVW & 0.95 & 1.1 & 1.2 & 1.25 & & & \\
\hline & & 2TRD & & $1.25\left(2^{2}\right)$ & $1.3\left(3^{2}\right)$ & & & & \\
\hline \multirow[t]{2}{*}{ N. parvulus } & $7274^{\prime} 6^{\prime \prime}$ & DVW & 1.05 & 1.3 & 1.4 & & & & \\
\hline & & 2TRD & & 1.5 & & & & & \\
\hline \multirow[t]{2}{*}{ N. parvulus } & $7286^{\prime} 71^{\prime \prime}$ & DVW & 0.95 & 1.15 & 1.2 & 1.3 & 1.5 & 1.5 & 1.5 \\
\hline & & 2TRD & & 1.25 & 1.35 & 1.6 & - & 1.6 & \\
\hline \multirow[t]{2}{*}{ N. parvulus } & $7292^{\prime} 3^{\prime \prime}$ & DVW & 1.0 & 1.25 & 1.35 & 1.4 & & & \\
\hline & & 2TRD & & 1.4 & 1.35 & & & & \\
\hline \multirow[t]{2}{*}{ N. targuii } & $7292^{\prime} 3^{\prime \prime}$ & DVW & - & 1.2 & 1.35 & 1.45 & & & \\
\hline & & 2TRD & & - & 1.55 & 1.9 & & & \\
\hline
\end{tabular}

